\title{
Genotype selection and addition of fertilizer increases grain yield in upland rice in Suriname
}

\author{
Adriano Stephan NASCENTE ${ }^{1 *}$, Ruby KROMOCARDI ${ }^{2}$ \\ 1 Embrapa Arroz e Feijão, Rodovia GO-462, Km 12, Fazenda Capivara, Zona Rural, CP 179, CEP 75375-000 - Santo Antônio de Goiás - GO, Brazil \\ 2 Ministry of Agriculture, Animal Husbandry and Fisheries, Letitia Vriesdelaan 8 - 10, Paramaribo, Suriname \\ * Corresponding author: adriano.nascente@embrapa.br
}

\begin{abstract}
The upland rice farmers in Suriname use local varieties and low level technologies in the field. As a result, the upland rice grain yield is low, at about $1000 \mathrm{~kg} \mathrm{ha}^{-1}$. Our objective was to evaluate the use of upland rice cultivars from Suriname and Brazil, and the effect of nitrogen, $\mathrm{N}$, phosphorus, $\mathrm{P}$, and potassium, $\mathrm{K}$, fertilizers on cultivation variables. We undertook four field trials in the Victoria Area, in the Brokopondo District, using a randomized block design each with four replications. The most productive rice varieties were BRS Esmeralda (grain yield $\left.2903 \mathrm{~kg} \mathrm{ha}^{-1}\right)$ and BRS Sertaneja $\left(2802 \mathrm{~kg} \mathrm{ha}^{-1}\right)$. The highest grain yield of $2620 \mathrm{~kg} \mathrm{ha}^{-1}$ was achieved with a top dressing application of $76.41 \mathrm{~kg} \mathrm{~N} \mathrm{ha}^{-1} 20$ days after sowing. For P, the highest grain yield of $3085 \mathrm{~kg} \mathrm{ha}^{-1}$ was achieved with application of $98.06 \mathrm{~kg} \mathrm{ha}^{-1} \mathrm{P}_{2} \mathrm{O}_{5}$ applied at sowing. An application rate of $31.45 \mathrm{~kg} \mathrm{ha}^{-1}$ of $\mathrm{K}_{2} \mathrm{O}$ at sowing achieved the highest grain yield of $2952 \mathrm{~kg} \mathrm{ha}^{-1}$. Together, these application rates of $\mathrm{N}$, $\mathrm{P}$ and $\mathrm{K}$ resulted in rice grain yield of about $3000 \mathrm{~kg} \mathrm{ha}^{-1}$, which is three times greater than the national average for upland rice. We demonstrate that the use of improved rice varieties matched to the local conditions, and application of appropriate fertilizers, are management practices that can result in significant increases in rice grain yield in Suriname.
\end{abstract}

KEYWORDS: Oryza sativa L., rice varieties, nitrogen, phosphorus, potassium

\section{Seleção de genótipos e adição de fertilizantes aumenta a produtividade de grãos do arroz de terras altas no Suriname}

\section{RESUMO}

Produtores de arroz de terras altas no Suriname usam cultivares locais e baixo nível tecnológico. Assim, a produtividade é baixa $\left(1000 \mathrm{~kg} \mathrm{ha}^{-1}\right)$. Nosso objetivo foi avaliar o uso de cultivares de arroz de terras altas do Suriname e do Brasil, e o efeito de taxas de nitrogênio, $\mathrm{N}$, fósforo, $\mathrm{P}$ e potássio, $\mathrm{K}$ sobre variáveis de cultivo. Foram instalados quatro ensaios de campo usando em cada experimento o delineamento de blocos casualizados com quatro repetiçóes. As mais produtivas cultivares de arroz foram BRS Esmeralda (produtividade de $2903 \mathrm{~kg} \mathrm{ha}^{-1}$ ) e a BRS Sertaneja (2 $\left.802 \mathrm{~kg} \mathrm{ha}^{-1}\right)$. A mais alta produtividade de grãos de $2620 \mathrm{~kg} \mathrm{ha}^{-1}$ foi alcançada pela aplicaçáo em cobertura de $76.41 \mathrm{~kg} \mathrm{~N} \mathrm{ha}^{-1}$, aos 20 dias após a semeadura. Para P, a mais alta produtividade de grãos de $2620 \mathrm{~kg} \mathrm{ha}^{-1}$ foi alcançada com a aplicaçáo de $98.06 \mathrm{~kg}^{-1} \mathrm{de}_{2} \mathrm{O}_{5}$ na semeadura. Uma aplicação da dose de $31.45 \mathrm{~kg} \mathrm{ha}^{-1} \mathrm{~K}_{2} \mathrm{O}$ na semeadura permitiu o maior rendimento de grãos, $2952 \mathrm{~kg} \mathrm{ha}^{2}$. Juntas, essas taxas de aplicação proporcionaram rendimento de grãos de arroz em torno de $3000 \mathrm{~kg} \mathrm{ha}^{-1}$, o que é três vezes maior que a média nacional do país para arroz de terras altas. $\mathrm{O}$ uso de variedades melhoradas de arroz adaptadas às condiçóes locais, e a aplicaçáo de doses adequadas de nutrientes são práticas de manejo que podem resultar em significativo aumento no rendimento de cultivos de arroz de terras altas no Suriname.

PALAVRAS-CHAVE: Oryza sativa L., variedades de arroz, nitrogênio, fósforo, potássio 


\section{INTRODUCTION}

The Republic of Suriname, with a land area of 163821 $\mathrm{km}^{2}$ (Milton 2009), is located on the northern coast of South America. However, only approximately 87000 ha are currently being utilized in rice production, with an additional 400000 ha of the interior region having agricultural potential (Milton 2012). Rice is the most important staple food in the country, comprising the basic component in the diet of the Surinamese people. Rice is cultivated on 28000 ha of the lowland areas, with a paddy production of 244 tons in the year 2012, of which 56 tons were exported, resulting in annual income of \$31.7 million (Derlagen et al. 2013).

Lowland rice production is undertaken on medium to large scale farms using modern production techniques oriented to supplying markets and produce grain yields up to $4800 \mathrm{~kg} \mathrm{ha}^{-1}$. In contrast, upland rice is cultivated in the inner regions of Suriname by the Maroon people of African descent. The main upland rice cultivation regions are located in the districts of Brokopondo and Sipaliwini (Fleskens and Jorritsma 2010). The farmers use local varieties and cultivate them with a traditional method without adding fertilizers, improved seeds, pesticides or mechanization. The resulting grain yields are low, rarely exceeding $1000 \mathrm{~kg} \mathrm{ha}^{-1}$ (Young and Angier 2010). While the climatic and soil conditions are generally favorable for upland rice production, biotic and abiotic factors such as diseases, pests, and the use of low yielding varieties limit productivity (Milton 2009). Low grain yields are problematic for the Maroon people who rely on rice as their staple food and current yields are not sufficient to meet the demand.

In most countries, the use of new cultivars from breeding programs is the principal solution to increase grain yield and meet food security needs. Improved cultivars provide increased grain yields and increase disease resistance. However, to recommend the use of the most appropriate cultivars for each region, seeds from different sources need to be evaluated by growing them in locations with a range of climate conditions and at different times throughout the year. The behavior of cultivars can vary in relation to the environment in which they are grown (Nascente et al. 2013). However, in Suriname there has been virtually no work on breeding for improved cultivars of upland rice. Many local varieties are planted, each one identified by the grain's red or white color. The cultivars used most widely are Topi Topi (red and white grain), Watra Lantie (white grain), and Koelie Alesi (red and white grain). We proposed that the evaluation of cultivars sourced from other countries, such as Brazil, and grown in Surinamese conditions in comparison with the local varieties, would be the most sensible approach to identify the most appropriate seed sources for the local conditions.
Further, additional gains in grain yield would be expected to result from improved fertilizer management. The use of a correctly balanced supply of nutrients from addition of fertilizers is expected to result in significant increases in grain yield (Fageria 2014b; Nascente et al. 2011; Nascente and Lanna 2016). Nitrogen, N, is the nutrient that most limits plant development, biomass and grain production in most crops (Fageria, 2014a). Estimates from reports in the literature suggest that productivity could be maximized with application rates between 40 and $180 \mathrm{~kg} \mathrm{ha}^{-1} \mathrm{~N}$ (Cazetta et al. 2008; Fageria 2014a). Phosphorus, P, is an essential element for plant metabolism and contributes significantly to increasing grain yield and root development. Further, several studies around the world have demonstrated the positive effect of adding $\mathrm{P}$ fertilizer on growth and grain yield of rice (Fageria et al. 2013; Nascente et al. 2014). Phosphorus is the nutrient that most limits the yield of rice, especially on low fertility soils such as those found in tropical regions (Fageria and Nascente 2014). Potassium is critical for photosynthesis and is needed for the activation of more than 60 enzymatic reactions in plants. Due to its high mobility, potassium moves rapidly from the oldest cells or plant tissue into storage in recently developed tissues and organs (Fageria et al. 2014b). Potassium is extracted from soils in large amounts by rice (Fageria et al. 2014b; Crusciol et al. 2016).

Our hypothesis was that the use of improved rice varieties and applications of N, P and K fertilizers would significantly increase rice grain yield in Suriname. Our objective was to evaluate the use of improved cultivars and appropriate rates of application of N, P and $\mathrm{K}$ fertilizers to increase rice grain yield in upland regions of Suriname.

\section{MATERIALS AND METHODS}

\section{Site description}

The experiments were conducted in the Victoria area of the District of Brokopondo, Suriname $\left(5.135^{\circ} \mathrm{N}, 54.986^{\circ}\right.$ $\mathrm{W}$, elevation above sea level $89 \mathrm{~m}$ ). The climate is classified as equatorial, fully humid (Af) in the Köppen Geiger system. Usually, four seasons are distinguished (Mulders and Bruin 1973; Climate Change 2015): a short rainy season, from mid-December to January; a short dry season from February to April; a long rainy season from May to mid-August; and a long dry season (mid-August to mid-December). Evaporation exceeds precipitation only during the long dry season. The mean annual rainfall over the period 1991-2015 was $2309 \mathrm{~mm}$ (Climate Change 2015). Maximum and minimum temperatures during the measurement period are shown in Figure 1. The soil is classified as Ferralsols (FAO system; Driessen and Dudal, 1991) or Oxisols (USDA Soil Taxonomy). Soil texture in the layer at depth $0-0.20 \mathrm{~m}$ comprised $762 \mathrm{~g} \mathrm{~kg}^{-1}$ sand, $66 \mathrm{~g} \mathrm{~kg}^{-1}$ of silt and $172 \mathrm{~g} \mathrm{~kg}^{-1}$ clay. 

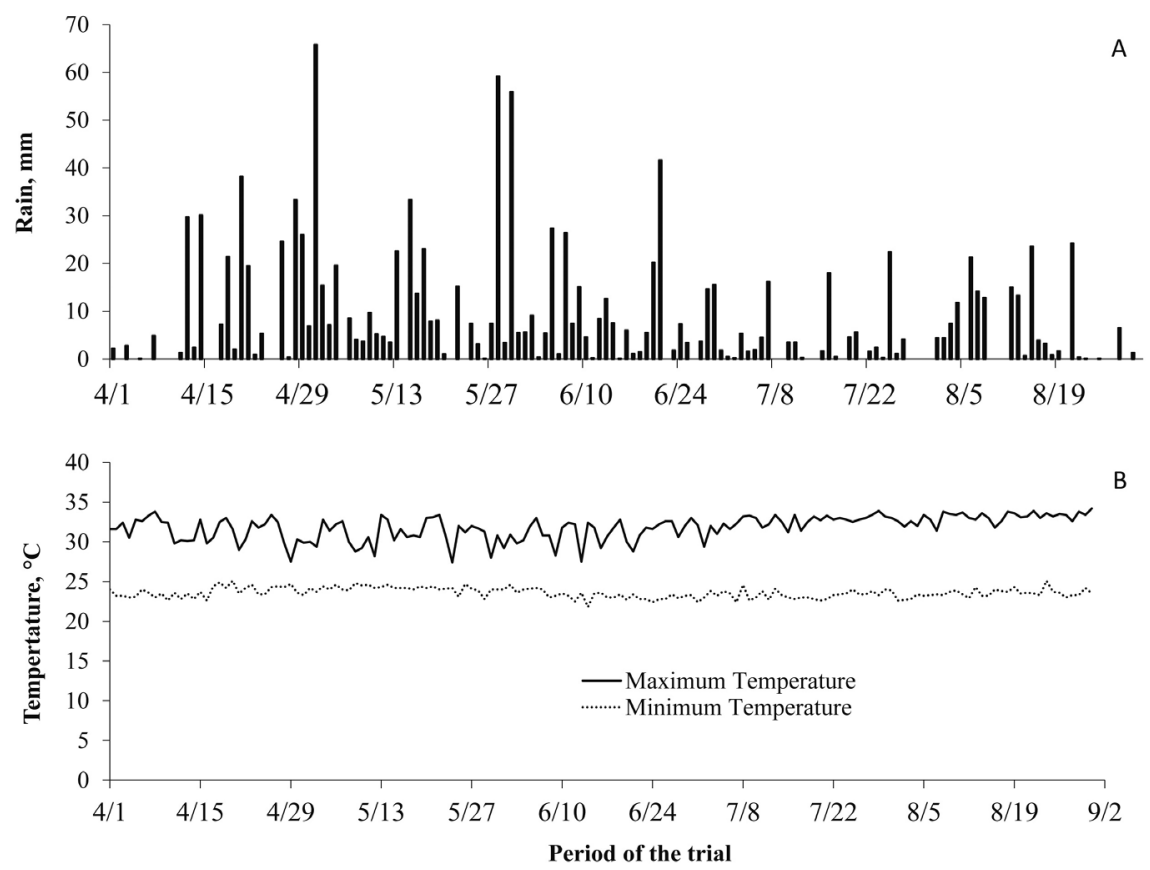

Figure 1. Rainfall $(A)$ and maximum and minimum temperatures (B) during the trial period at the research site in Victoria, District of Brokopondo, Suriname during the 2016 rice growing season.

Prior to the study, in April 2016, soil samples from a depth range of 0-0.20 m were collected for chemical analyses using methods following Donagema et al. (2011) to record the properties at the start of the experimental period (Table 1).

Experimental trials were undertaken in rain-fed conditions without the use of irrigation. The soil was plowed 30 days prior to sowing, followed by leveling three days prior to sowing. On the day of sowing (27 April 2016) a further soil leveling was carried out. Opening of the rows and seed sowing was done by hand with a sowing rate of 230 seeds $\mathrm{m}^{-2}$. On average, rice plant emergence occurred four days after sowing. Trial plots were arranged in a randomized complete block design with four replicates. Plot dimensions were $2.1 \times 5 \mathrm{~m}$, with six 2.1 - $\mathrm{m}$ rows, and $0.35 \mathrm{~m}$ between rows. Measurements were made in the usable area, four central rows of rice, disregarding each outer row and the plants growing in the outer $0.50 \mathrm{~m}$ of each row.

\section{Trial 1 - Evaluation of upland rice genotypes}

Treatments comprised seven upland rice genotypes (four from Brazil: BRS Pepita, BRSMG Curinga, BRS Esmeralda, BRS Sertaneja, and three local varieties from Suriname: TopiTopi, Watra Lantie, and Koelie Alesi). At the time of sowing, fertilizers were applied by hand along the base of each row at the rates of $20 \mathrm{~kg} \mathrm{ha}^{-1}$ of $\mathrm{N}$ as urea, $100 \mathrm{~kg} \mathrm{ha}^{-1}$ of $\mathrm{P}_{2} \mathrm{O}_{5}$ as triple superphosphate, and $60 \mathrm{~kg} \mathrm{ha}^{-1}$ of $\mathrm{K}_{2} \mathrm{O}$, as Patentkali ${ }^{\circledR}$.
Topdressing with nitrogen occurred 20 and 40 days after rice emergence, each with $40 \mathrm{~kg} \mathrm{ha}^{-1}$ of $\mathrm{N}$ as urea.

\section{Trial 2 - Evaluation of the application of nitrogen (N) fertilizer as topdressing}

The seed source for this trial was Topi-Topi because this is the most widely cultivated local variety in Suriname. Fertilizers were applied at sowing at rates of $10 \mathrm{~kg} \mathrm{ha}^{-1}$ of N as urea, 100 $\mathrm{kg} \mathrm{ha}^{-1}$ of $\mathrm{P}_{2} \mathrm{O}_{5}$ as triple superphosphate, and $60 \mathrm{~kg} \mathrm{ha}^{-1}$ of $\mathrm{K}_{2} \mathrm{O}$ as Patentkali ${ }^{\circledast}$ were applied along the base of each row. The first topdressing treatments comprised four rates of $\mathrm{N}(0$, 40,80 and $120 \mathrm{~kg} \mathrm{ha}^{-1} \mathrm{~N}$ as urea) applied at the beginning of the tiller stage (around 20 days after emergence). The second topdressing was applied at 40 days after rice emergence with $40 \mathrm{~kg} \mathrm{ha}^{-1}$ of $\mathrm{N}$ as urea.

\section{Trial 3 - Evaluation of the application of phosphorus (P) fertilizer}

The seed source for this trial was Topi-Topi. Treatments comprised four rates of $\mathrm{P}_{2} \mathrm{O}_{5}\left(0,40,80\right.$ and $120 \mathrm{~kg} \mathrm{ha}^{-1}$ as triple superphosphate) applied along the base of each row prior to sowing. Nitrogen and potassium were broadcast on the soil surface after sowing at the rates of $10 \mathrm{~kg} \mathrm{ha}^{-1} \mathrm{~N}$ as urea and $60 \mathrm{~kg} \mathrm{ha}^{-1} \mathrm{~K}_{2} \mathrm{O}$, as Patentkali ${ }^{\circledR}$. Topdressing $\mathrm{N}$ was applied at 20 and 40 days after rice emergence, each at the rate of $40 \mathrm{~kg} \mathrm{ha}^{-1} \mathrm{~N}$ as urea. 
Table 1. Chemical characteristics of the soil at the experimental sites in Victoria, District of Brokopondo, Suriname in April 2016.

\begin{tabular}{lcc}
\hline Paremeter & Unit & Value \\
\hline $\mathrm{Ca}$ & $\mathrm{cmol}_{\mathrm{c}} \mathrm{kg}^{-1}$ & 3.4 \\
$\mathrm{Mg}$ & $\mathrm{cmol}_{\mathrm{c}} \mathrm{kg}^{-1}$ & 1.5 \\
$\mathrm{Al}$ & $\mathrm{cmol}_{\mathrm{c}} \mathrm{kg}^{-1}$ & 0.0 \\
$\mathrm{H}+\mathrm{Al}$ & $\mathrm{cmol}_{\mathrm{c}} \mathrm{kg}^{-1}$ & 3.1 \\
$\mathrm{~K}$ & $\mathrm{cmol}_{\mathrm{c}} \mathrm{kg}^{-1}$ & 0.16 \\
$\mathrm{CEC}$ & $\mathrm{cmol}_{\mathrm{c}} \mathrm{kg}^{-1}$ & 8.16 \\
$\mathrm{pH}\left(\mathrm{CaCl}_{2}\right)$ & - & 5.6 \\
$\mathrm{BS}{ }^{1}$ & ${ }^{\circ}$ & 62.00 \\
$\mathrm{SOM}$ & 35.7 \\
$\mathrm{P}$ & $\mathrm{g} \mathrm{kg}^{-1}$ & 15.8 \\
$\mathrm{Zn}$ & $\mathrm{mg} \mathrm{kg}^{-1}$ & 3.8 \\
$\mathrm{Cu}$ & $\mathrm{mg} \mathrm{kg}^{-1}$ & 2.3 \\
$\mathrm{Fe}$ & $\mathrm{mg} \mathrm{kg}^{-1}$ & 27.1 \\
$\mathrm{Mn}$ & $\mathrm{mg} \mathrm{kg}^{-1}$ & 34.3 \\
\hline
\end{tabular}

${ }^{1}$ Base saturation. ${ }^{2}$ Soil organic matter. ${ }^{3}$ Cation exchange capacity.

\section{Trial 4 - Evaluation of the application of potassium (K) fertilizer}

The seed source for this trial was Topi-Topi and applications of $\mathrm{P}$ and $\mathrm{N}$ were spread along the base of each row prior to sowing. Treatments comprised four rates of $\mathrm{K}_{2} \mathrm{O}$ $\left(0,20,40\right.$ and $60 \mathrm{~kg} \mathrm{ha}^{-1}$ as Patentkali $\left.{ }^{\mathbb{\circledR}}\right)$ broadcast on the soil surface after sowing at the rate of $10 \mathrm{~kg} \mathrm{ha}^{-1} \mathrm{~N}$ as urea and $100 \mathrm{~kg} \mathrm{ha}^{-1} \mathrm{P}_{2} \mathrm{O}_{5}$ as triple superphosphate. Topdressing $\mathrm{N}$ was applied at 20 and 40 days after rice emergence each at the rates of $40 \mathrm{~kg} \mathrm{ha}^{-1}$ as urea.

\section{Upland rice management}

In all trials, Karate ${ }^{\circledR}$, Syngenta insecticide (lamdacyhalothrin) was applied at the rate of $150 \mathrm{ml} \mathrm{ha}^{-1}(7.5 \mathrm{~g}$ active ingredient ha $\left.^{-1}\right)$ at 20,30, 50, 60 and 75 days after emergence of the rice. Weeding by hand was done each week and Nativo ${ }^{\circledR}$, Bayer CropScience fungicide (trifloxystrobin $25 \% \mathrm{w} / \mathrm{w}+$ tebuconazole $50 \% \mathrm{w} / \mathrm{w}$ ) was applied at 80 days after emergence.

\section{Measurements of traits}

Dry matter production (PDMP) was measured at the full flowering stage (Pepita $=52$ days after emergence, DAE; Curinga, Esmeralda and Sertaneja $=66$ DAE; Watra Lantie and Koelie Alesie $=81$ DAE; Topi Topi $=88$ DAE) by harvesting rice shoots from $1 \mathrm{~m}^{2}$ in each plot. The plant material was placed in an oven at $60 \mathrm{C}$ until it reached constant mass, and was then weighed. Grain production was measured by hand after the grain reached physiological maturity in each plot $($ Pepita $=91$ DAE; Curinga, Esmeralda and Sertaneja $=$ 99 DAE; Watra Lantie, Koelie Alesie and Topi-Topi $=120$ $\mathrm{DAE}$ ). The number of tillers (NT) was determined for each plot by measuring 10 plants. Plant height $(\mathrm{PH})$ was measured as the distance between the soil surface and the height of the tallest panicle on plants at the time when the crop was at the phenological stage of milky grains. The grain yield of rice is determined by three components: (i) the number of panicles per unit area, (ii) the number of grains per panicle, and (iii) the mass per 1000 grains (Yoshida 1981; Nascente et al. 2013). So, the number of panicles per unit area (PAN) was determined by counting their number within a $1 \mathrm{~m}$ length of one of the rows, randomly selected in the usable area of each plot. Number of grains per panicle (GRAIN), was determined by counting the number of grains in 10 panicles randomly sampled in the usable area and divided by 10 . The mass of 1 000 grains (MGRAIN) was determined by weighing grains from a random collection with a correction to $13 \%$ of water content (Yoshida 1981; Nascente et al. 2013). Total grain yield (YIELD) for each plot was determined by weighing all the harvested grain from each plot, corrected to $13 \%$ water content.

\section{Statistical analyses}

Analysis of variance was used to test for significant differences and, when differences proved to be significant, the data were compared by a Tukey test at $\mathrm{p}<0.05$. For data from different rates of application of fertilizers, if differences were significant, regression analyses were undertaken. All analyses were done using SAS Statistical Software (SAS Institute, Cary, NC, USA).

\section{RESULTS}

Plant height for the Surinamese varieties was greater than that of the Brazilian varieties (Table 2). PDMP and PAN did not vary significantly among varieties, $\mathrm{NT}$ and $\mathrm{PH}$ were significantly higher for Suriname varieties, GRAIN, MGRAIN and YIELD were significantly higher for BRS Esmeralda and BRS Sertaneja than for all other varieties, and BRSMG Curinga, though significantly lower than BRS Esmeralda and BRS Sertaneja, had significantly higher MGRAIN and YIELD than Suriname varieties and BRS Pepita.

Addition of $\mathrm{N}$ fertiliser in the range of 0 to $120 \mathrm{~kg} \mathrm{~N} \mathrm{ha}^{-1}$ significantly increased the response of all variables, except the number of tillers (Table 3, Table 4). The response of the variables to the increase in $\mathrm{N}$ were described by a quadratic function (Figure. 2). According to the model, the highest grain yield (2 $620 \mathrm{~kg}$ ha-1) was estimated when $\mathrm{N}$ was applied as topdressing (20 days after sowing) at a rate of $76.41 \mathrm{~kg} \mathrm{ha}^{-1}$

The application of P from 0 to $120 \mathrm{~kg} \mathrm{P} 2 \mathrm{O} 5 \mathrm{ha}^{-1}$ also increased significantly the response of all variables, except the 
Table 2. Plant dry matter production (PDMP), plant height (PH), number of tillers (NT), number of panicles (PAN), number of grains per panicle (GRAIN), mass of 1000 grains (MGRAIN) and grain yield (YIELD) for rice of different varieties during the 2016 growing season. Values are means of four replicates. Different letters in a column indicate significant differences according to Tuckey test at $p<0.05$.

\begin{tabular}{lccccccc}
\hline Rice variety & $\begin{array}{c}\text { PDMP } \\
\mathrm{g} \mathrm{m}^{-1}\end{array}$ & $\begin{array}{c}\mathrm{PH} \\
\mathrm{cm}\end{array}$ & $\begin{array}{c}\mathrm{NT} \\
\mathrm{m}^{-1}\end{array}$ & $\begin{array}{c}\text { PAN } \\
\mathrm{m}^{-2}\end{array}$ & $\begin{array}{c}\text { GRAIN } \\
\text { panicle } \mathrm{e}^{-1}\end{array}$ & $\begin{array}{c}\text { MGRAIN } \\
\mathrm{g}\end{array}$ & $\begin{array}{c}\text { YIELD } \\
\mathrm{kg} \mathrm{ha}^{-1}\end{array}$ \\
\hline Topi-Topi & $568 \mathrm{a}$ & $111 \mathrm{a}$ & $127 \mathrm{ab}$ & $234 \mathrm{a}$ & $40.43 \mathrm{~b}$ & $11.82 \mathrm{bc}$ & $1521 \mathrm{~b}$ \\
Watra-Lantie & $473 \mathrm{a}$ & $109 \mathrm{a}$ & $100 \mathrm{bc}$ & $198 \mathrm{a}$ & $58.38 \mathrm{ab}$ & $13.38 \mathrm{bc}$ & $1670 \mathrm{~b}$ \\
Koelie-Alesi & $489 \mathrm{a}$ & $111 \mathrm{a}$ & $150 \mathrm{a}$ & $197 \mathrm{a}$ & $36.05 \mathrm{~b}$ & $9.10 \mathrm{c}$ & $1150 \mathrm{~b}$ \\
BRS smeralda & $417 \mathrm{a}$ & $76 \mathrm{~b}$ & $83 \mathrm{bc}$ & $229 \mathrm{a}$ & $85.05 \mathrm{a}$ & $26.31 \mathrm{a}$ & $2903 \mathrm{a}$ \\
BRS Pepita & $289 \mathrm{a}$ & $69 \mathrm{~b}$ & $68 \mathrm{c}$ & $189 \mathrm{a}$ & $58.25 \mathrm{ab}$ & $15.30 \mathrm{bc}$ & $1153 \mathrm{~b}$ \\
BRS Sertaneja & $414 \mathrm{a}$ & $83 \mathrm{~b}$ & $86 \mathrm{bc}$ & $252 \mathrm{a}$ & $85.08 \mathrm{a}$ & $25.89 \mathrm{a}$ & $2802 \mathrm{a}$ \\
BRSMG Curinga & $379 \mathrm{a}$ & $69 \mathrm{~b}$ & $74 \mathrm{c}$ & $211 \mathrm{a}$ & $58.80 \mathrm{ab}$ & $17.93 \mathrm{ab}$ & $2255 \mathrm{ab}$ \\
\hline Factor & & & & ANOVA (F probability) & & & \\
Rice varieties & 0.3835 & $<0.001$ & 0.0002 & 0.5339 & 0.0015 & $<0.001$ & 0.0028 \\
\hline
\end{tabular}
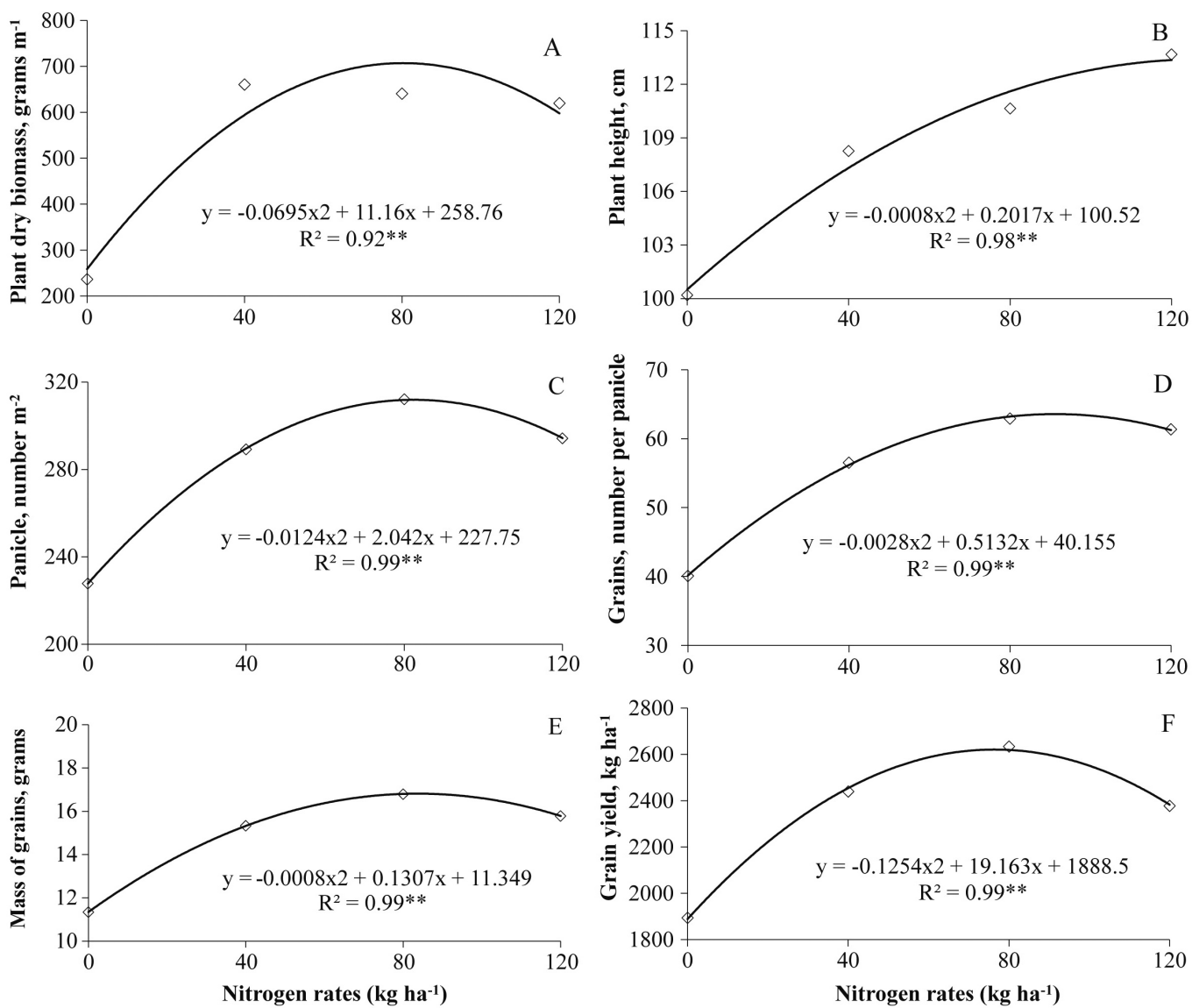

Figure 2. Plant dry biomass (A), plant height (B), number of panicles $(C)$, number of grains per panicle (D), mass of 1000 grains $(E)$ and grain yield $(F)$ for the variety Topi-Topi in response to different rates of application of nitrogen as urea. 
number of grains per panicle (Table 3, Table 4). The increase also fitted a quadratic function (Figure 3), with the highest grain yield of $3085 \mathrm{~kg} \mathrm{ha}^{-1}$ attained for a $\mathrm{P}_{2} \mathrm{O}_{5}$ application of $98.06 \mathrm{~kg} \mathrm{ha}^{-1}$. Applications of $\mathrm{K}$ from 0 to $60 \mathrm{~kg} \mathrm{ha}^{-1}$ showed significant effects on plant dry biomass, number of tillers, mass of 1000 grains and grain yield (Table 3, Table 4). The increase in the values of these variables conformed to a quadratic function (Figure 4), the highest grain yield of 2 $952 \mathrm{~kg} \mathrm{ha}^{-1}$ being attained for an application of $\mathrm{K}_{2} \mathrm{O}$ at sowing of $31.45 \mathrm{~kg} \mathrm{ha}^{-1}$.
Table 4. Grain yields of the rice variety Topi-Topi in response to applications at different rates of nitrogen, phosphorus or potassium in the 2016 growing season. All units in $\mathrm{kg} \mathrm{ha}^{-1}$. Numbers are means of four replicates. The bottom line indicates the application rate resulting in the highest grain yield according to the quadratic function models in Figures $2 F, 3 F$ and $4 \mathrm{D}$, respectively.

\begin{tabular}{lccccc}
\hline N rate & Yield & $\mathrm{P}_{2} \mathrm{O}_{5}$ rate & Yield & $\mathrm{K}_{2} \mathrm{O}$ rate & Yield \\
\hline 0 & 1893 & 0 & 1674 & 0 & 2429 \\
40 & 2440 & 40 & 2842 & 20 & 2772 \\
80 & 2634 & 80 & 2815 & 40 & 3016 \\
120 & 2378 & 120 & 3094 & 60 & 2457 \\
76.41 & 2620 & 98.06 & 3085 & 31.45 & 2952 \\
\hline
\end{tabular}

Table 3. F probability of ANOVA for plant dry matter production (PDMP), plant height (PH), number of tillers (NT), number of panicles (PAN), number of grains per panicle (GRAIN), mass of 1000 grains (MGRAIN) and grain yield (YIELD) of the rice variety Topi-Topi in response to different rates of application of nitrogen, phosphorus and potassium in the 2016 growing season.

\begin{tabular}{lccccccc}
\hline Fertilizer & PDMP & PH & NT & PAN & GRAIN & MGRAIN & YIELD \\
\hline $\mathrm{N}$ & 0.0006 & 0.0067 & 0.8533 & 0.0102 & 0.0468 & 0.02640 & 0.0401 \\
$\mathrm{P}_{2} \mathrm{O}_{5}$ & 0.0346 & 0.0099 & 0.2373 & 0.0035 & 0.1667 & 0.0454 & 0.0426 \\
$\mathrm{~K}_{2} \mathrm{O}_{5}$ & 0.0263 & 0.2477 & 0.0118 & 0.2704 & 0.0393 & 0.1123 & 0.0484 \\
\hline
\end{tabular}
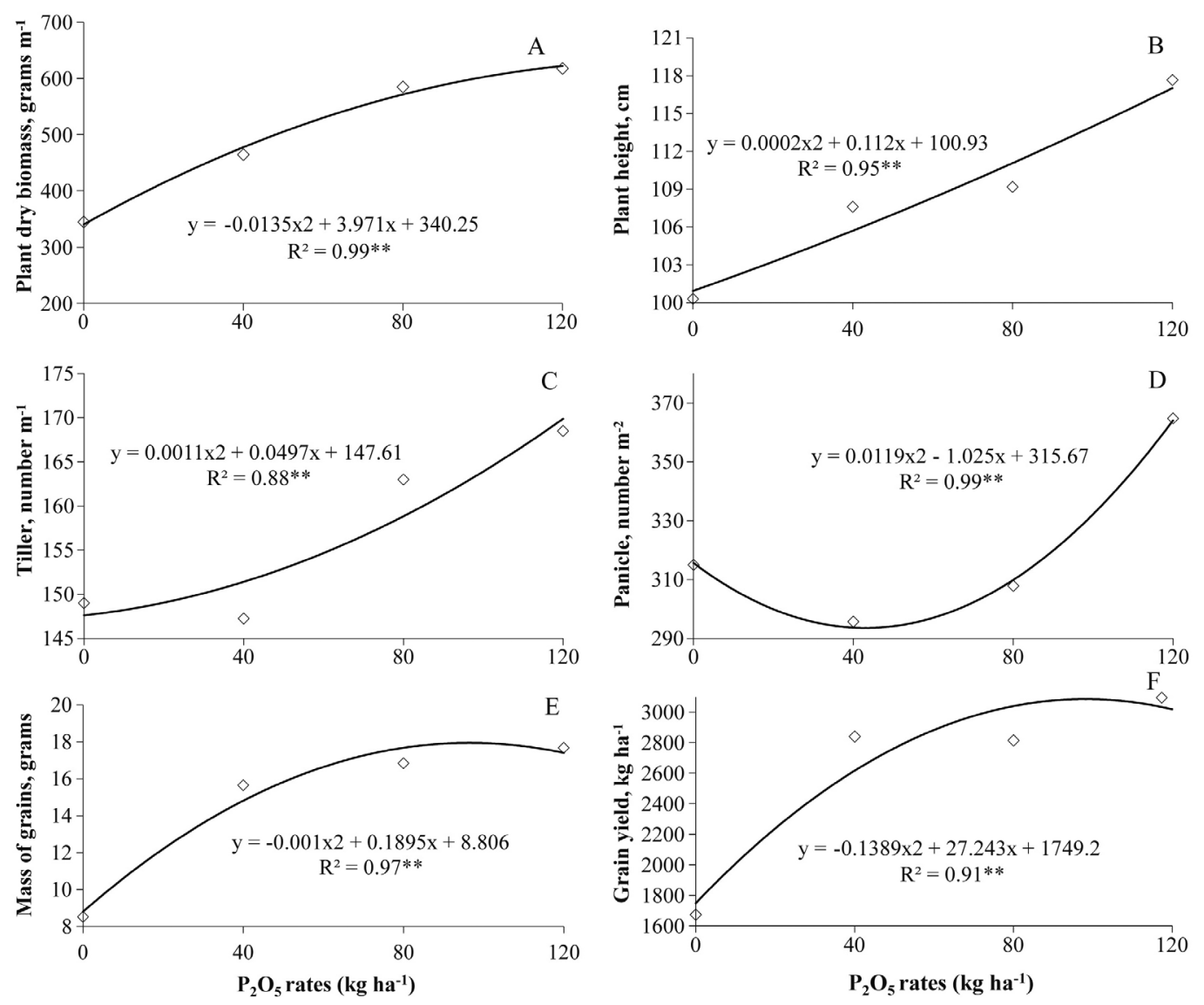

Figure 3. Plant dry biomass (A), plant height (B), number of tillers $(C)$, number of panicles (D), mass of 1000 grains $(E)$ and grain yield $(F)$ for the variety Topi-Topi in response to different rates of application of phosphorus as $\mathrm{P}_{2} \mathrm{O}_{5}$. 

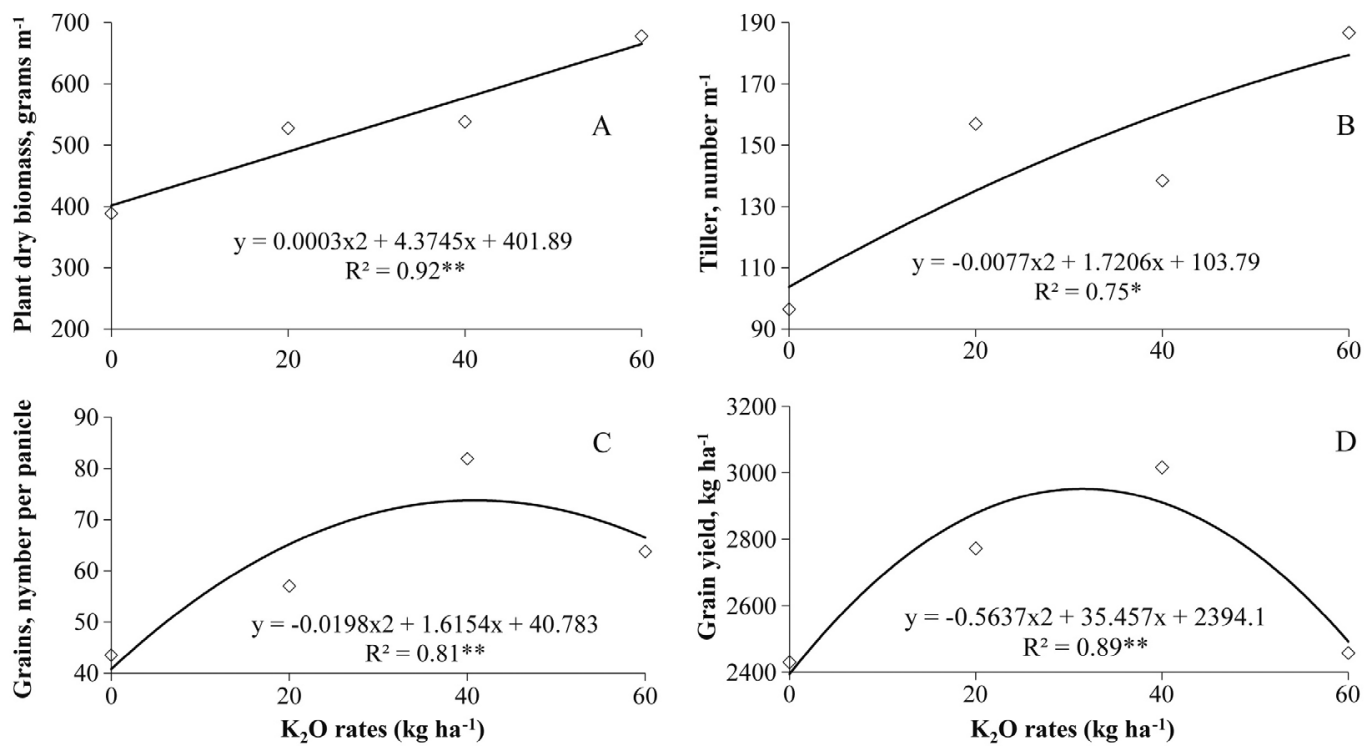

Figure 4. Plant dry biomass (A), number of tillers (B), number of grain per panicle $(C)$ and grain yield (D) for the variety Topi-Topi in response to different rates of application of potassium as $\mathrm{K}_{2} \mathrm{O}$.

\section{DISCUSSION}

\section{Effects of different upland rice varieties}

The greater plant height of the Creole varieties likely makes them more prone to lodging. The Brazilian varieties that were developed from breeding programs were shorter in height (less then $1 \mathrm{~m}$ ) and this protects against lodging (Art $e t$ al. 2015). There is a strong correlation between plant height and the susceptibility to lodging at the end of the crop cycle (Silva et al. 2010; Alvarez et al. 2014).

In rice, the number of tillers correlates strongly with grain yield (Sangoi et al. 2011). However, two of the Creole varieties, Koelie-Alesi and Topi-Topi, produced more tillers but no increase in grain yield compared with the other varieties. This is because the other varieties were not improved to produce one panicle for each tiller, as occurs in improved cultivars of the Brazilian varieties (Santos et al. 2006). For example, the number of tillers for the BRS Esmeralda (83) and BRS Sertaneja (86) varieties were lower than those for Koelie-Alesi (150) and Topi-Topi (127), and produced numbers of panicles per unit area that were similar to those for the Creole varieties.

The high grain yields for BRS Esmeralda (2903 kg ha-1), BRS Sertaneja (2 $\left.802 \mathrm{~kg} \mathrm{ha}^{-1}\right)$ and BRSMG Curinga (2 255 $\mathrm{kg} \mathrm{ha}^{-1}$ ) can be explained by the higher number of panicles, number of grains per panicle and mass of grains in comparison with the Surinamese varieties.

It is important to note that wheather conditions during the trial period were favorable for rice growth (Figure 1), and allowed rice grain yields of all varieties to reach more than the average national production of upland rice of $1000 \mathrm{~kg}$ $\mathrm{ha}^{-1}$. Our findings indicate that the Brazilian varieties BRS Esmeralda, BRS Sertaneja and BRSMG Curinga may produce grain yields under Surinamese conditions that more than double the current average of upland rice production of the country, and may provide a good opportunity for the Maroon people to increase productivity and improve food security. It has to be noted, however, that the use of pesticides and fertilizers likely played a significant role in the achievement of increased rice grain yield in our trials. Under the lowtechnology cultivation conditions in the interior of Suriname, including the lack of chemical treatments (Young and Angier 2010), the yield of the cultivars from Brazil should be lower than that achieved in our trials.

\section{Effects of fertilizer appication}

We have demonstrated that appropriate applications of $\mathrm{N}$ at topdressing resulted in significant increases in rice grain yield. A positive effect of nitrogen application on rice production was also achieved in the Cerrado region of central Brazil (Lacerda and Nascente 2016). The Cerrado has more than 200 million ha available for rice production, but the soils are naturally acidic because of high levels of rainfall which, over many years, has leached soil ions, so reducing soil fertility (Fageria and Nascente, 2014). Nitrogen supply is essential for cell structure and function, all enzymatic reactions in the plant, and is an important constituent of the chlorophyll required for photosynthesis (Fageria 2014). Therefore, it is not surprising that we observed increased plant growth and development with $\mathrm{N}$ application in our trial. Nitrogen is the 
nutrient that mostly affects plant height in rice (Arf et al. 2005, Buzetti et al. 2006, Hernandes et al. 2010, Mattje et al. 2013, Lacerda and Nascente 2016), also increasing biomass production and yield components (Arf et al. 2005; Cazetta et al. 2008; Cancellier et al. 2011; Nascente et al. 2011; Lacerda and Nascente 2016).

The positive effect of phosphorus on plant dry biomass, plant height, number of panicles, mass of grains and grain yield was expected because $P$ contents in the soil were low (see Table 1). Our findings confirm those from other reports showing the response of rice to the addition of $\mathrm{P}$ fertilizer (Barberena et al. 2011, Fageria et al. 2013, Nascente et al. 2014).

The observed increase in plant dry biomass, plant tillering, panicle density, number of grains per panicle and grain yield as a response to potassium application support other studies on the positive effects of $\mathrm{K}$ application on rice grain yield in the Cerrado region and elsewhere (Zaratin et al. 2004; Fageria et al. 2011; Fageria 2015). According to Fageria (2015), 17\% of the agricultural land area is deficient in potassium in Africa, $21 \%$ in Asia and 29\% in Latin America.

Appropriate applications of $\mathrm{N}, \mathrm{P}$ and $\mathrm{K}$ resulted in rice grain yields up to $3000 \mathrm{~kg} \mathrm{ha}^{-1}$, which is three times more than the national average for upland rice production in Suriname. Our data cannot be applied to all soil types and climate conditions across the country, but our findings signal the potential for further research to increase the yield of the staple crop of Suriname.

\section{Application in upland rice production}

The Maroon people who plant rice in the interior region of Suriname have very limited financial capital and low education level (Milton 2012). Thus, they likely use low-level technologies because they do not have access to and cannot afford modern technologies. In this sense, the Ministry of Agriculture of Suriname is collaborating with Brazil (Embrapa and the Brazilian Cooperation Agency - ABC) and the New Zealand Embassy to develop technologies that allow the increase of rice grain yields in Suriname, including the present study. The cooperation involves training of upland farmer communities in rice seed production and rice cultivation techniques. The introduction of high-yield rice varieties to low-income upland communities will ideally require a policy of subsidies that allows farmers access to supplies such as fertilizers and pesticides to enhance their crops.

\section{CONCLUSIONS}

Our research is the first to be undertaken for upland rice production in Suriname. We have demonstrated that the use of improved technologies for rice cultivation, including the use of seeds from improved varieties, weed control and addition of fertilizers, can result in substantial increases in grain yield above those for average upland rice yield in Suriname. BRS Esmeralda and BRS Sertaneja were the rice varieties that led to highest rates of grain yields. The highest rates of production from appropriate application rates of N, P and $\mathrm{K}$ fertilizers resulted in rice grain yield up to $3000 \mathrm{~kg} \mathrm{ha}^{-1}$ which is three times more than the national average. Application of our findings, if coupled with adequate incentive and education programs, could provide low-income farmers in the interior upland regions of Suriname with the opportunity to increase the yield for their staple food, improving their income and food security.

\section{ACKNOWLEDGEMENTS}

We are grateful to the New Zealand Embassy, Brazilian Agency of Cooperation and Embrapa for financial support for this work. The Ministry of Agriculture, Animal Husbandry and Fisheries of Suriname helped with the establishment and management of the field trials. To Professor David Whitehead for English revision. To the National Council for Scientific and Technological Development (CNPq) for an award for excellence in research to the first author.

\section{REFERENCES}

Alvarez, R.C.F.; Crusciol, C.A.C.; Nascente, A.S. 2014. Upland rice yield as a function of growth regulators. Revista Ceres, 61: 42-49.

Arf, O.; Rodrigues, R.A.F.; Nascente, A.S.; Lacerda, M.C. 2015. Early nitrogen fertilization in the crop of upland rice under no-tillage. Revista de Ciências Agrárias, 58: 6-13.

Barberena, D.S.; Medeiros, R.D.; Barbosa, G.F. 2011. Growth and productivity of irrigated rice in response to different doses of phosphorus and potassium in lowland soil of first year in the state of Roraima. Ciência \& Agrotecnologia, 35: 462-470.

Cazetta, D.A.; Arf, O.; Buzetti, S.; Sá, M.E.; Rodrigues, R.A.F. 2008. Performance of upland rice to the nitrogen rates after different cover crops in no-till system. Bragantia, 67: 471-479.

Climate Change Knowledge Portal, 2015. Average monthly temperature and rainfall for Suriname from 1901-2015. (http:// sdwebx.worldbank.org/climateportal/index.cfm?page $=$ country_ historical_climate\&ThisCCode=SUR). Accessed on 22/05/2017.

Crusciol, C.A.C.; Fernandes, A.M.; Carmeis Filho, A.C.A.; Alvarez, R.C.F. 2016. Macronutrient uptake and removal by upland rice cultivars with different plant architecture. Revista Brasileira de Ciência do Solo, 40: 1-20.

Derlagen, C.; Barreiro-Hurlé, J.; Shik, O. 2013. Agricultural Sector Support in Suriname. (http://www.gov.sr/media/968294/ agricultural_sector_support_in_suriname.pdf). Acessed on 22/05/2017.

Donagema, G.K.; Campos, D.V.B.; Calderano, S.B.; Teixeira, W.G. 2011. Manual de métodos de análise de solo. 2nd ed. Embrapa Solos, Rio de Janeiro, 230p. 
Fageria, N.K.; Nascente, A.S. 2014. Management of Soil Acidity of South American Soils for Sustainable Crop Production. Advances in Agronomy, 128: 221-275.

Fageria, N. K. 2014b. Mineral nutrition of rice. CRC Press, Boca Raton, 586p.

Fageria, N.K.; Moraes, O.P.; Vasconcelos, M.J. 2013. Upland rice genotypes evaluation for phosphorus use efficiency. Journal of Plant Nutrition, 36: 1868-1880.

Fageria, N.K. 2014a. Nitrogen management in crop production. CRC Press, Boca Raton, 436p.

Fageria, N.K. 2015. Potassium Requirements of Lowland Rice. Communications in Soil Science and Plant Analysis, 46: 14591472.

Fageria, N.K.; Baligar, V.C.; Jones, C.A. 2011. Growth and mineral nutrition of field crops. 3rd ed. CRC Press, Boca Raton, 586p.

Fleskens, L.; Jorritsma, F. 2010. A behavioral change perspective of maroon soil fertility management in traditional shifting cultivation in Suriname. Human Ecology, 38: 217-236.

Lacerda, M.C.; Nascente, A.S. 2016. Effects of row spacing and nitrogen topdressing fertilization on the yield of upland rice in a no-tillage system. Acta Scientiarum. Agronomy, 38: 493-502.

Milton, P.Y. (Comp.). Plant genetic resources of Suriname (country report). 2012. (http://www.fao.org/pgrfa-gpa-archive/sur/docs/ PGR\%20Country\%20Report\%20Suriname\%202012.pdf). Accessed on 10/10/2016.

Milton, P.Y. Plant genetic resources of Suriname (country report). 2009. (http://www.fao.org/docrep/013/i1500e/Suriname.pdf).

Accessed on 10/10/2016.

Mulders, M.A.; Bruin, L.P.H. 1973. Climatological aspects of the Afobaka area. Report nr. 117. Dienst Bodem Kartering, Paramaribo, Suriname, 9p.
Nascente, A.S.; Kluthcouski, J.; Cobucci, T.; Rabelo, R.R.; Oliveira, P.; Crusciol, C.A.C. 2011. Upland rice yield under different soil management systems and nitrogen application times. Pesquisa Agropecuária Tropical, 41: 60-65.

Nascente, A.S.; Oliveira, P.; Kluthcouski, J.; Freitas, R.J.; Favarin, J.L. 2013. Cultivares de arroz de terras altas afetadas pelo manejo do solo. Revista Brasileira de Ciências Agrárias, 8: 428-434.

Nascente, A.S.; Lanna, A.C. 2016. Straw and early nitrogen fertilization on soil properties and upland rice productivity. Pesquisa Agropecuaria Tropical, 46: 284-291.

Nascente, A.S.; Lacerda, M.C.; Carvalho, M.C.S.; Mondo, V. H. 2014. Gypsum and phosphorus in the development of upland rice under a no-tillage system. African Journal of Agricultural Research, 9: 3645-3654.

Santos, A.B.; Stone, L.F.; Vieira, N.R.A. 2006. A cultura do arroz no Brasil. 2nd ed. Embrapa Arroz e Feijāo, Santo Antônio de Goiás, 1000p.

Yoshida, S. 1981. Fundamentals of Rice Crop Science. IRRI, Laguna, Los Baños, 269p.

Young, G.; Angier, P. Developing a fair trade certification label for rice exports from Guyana and Suriname: a project commissioned by Imani Development on behalf of the Caribbean Rice Association. 2010. (http://www.angier-griffin.com/downloads/2011/ january/Final\%20Report\%20Text\%20(01.10).pdf). Accessed on $10 / 10 / 2016$

Zaratin, C.; Souza, S.A.; Pantano, A.C.; Sá, M.E.; Arf, O.; Buzetti, $S$. Efeitos de quatro doses de potássio em seis cultivares de arroz de sequeiro irrigados por aspersão. Cientifica 32: 115- 120.

Receveid: 24/01/2017

Accepted: 13/06/2017 
